\title{
Sustainability Reporting: Case of European Stock Companies
}

\author{
By Adrian Gawęda ${ }^{1}$
}

\begin{abstract}
Sustainability reporting regulations defined within NFRD (Non-Financial Reporting Directive) allow different stakeholders to assess ESG (Environmental, Social and Governance) performance of companies and their impact on people and environment. ESG data is increasingly used in strategy definition of entities, investment decision-making process and valuation of stock companies. ESG information is also reflected in ESG ratings which create comprehensive measure of ESG performance of specific entity. It outlines the need for dissemination of true and fair corporate sustainability reporting system. The main purpose of undertaken work is to evaluate the trend and evolution of sustainability reporting and ESG ratings of European listed companies in 2000-2020 period. In order to deliver results comparative analysis is used. Research proves that vast majority of European stock companies do not provide enough ESG performance which does not allow to assign them with appropriate ESG rating. Findings of analysis indicate the size of sustainability reporting accountability gap and confirm that wider group of public interest entities should be subject of NFRD.
\end{abstract}

Keywords: sustainability reporting, ESG rating, stock companies

\section{Introduction}

In recent decades, one of the leading economic theories in the field of corporate finance was the concept of Shareholder Value Approach (Choi and Wang 2009). According to this approach, the main aim of a company is to maximize its value, or more precisely, the value for shareholders (Rappaport 1986). Changes in the economic environment, however, force market participants to adapt to new conditions and cause a redefinition of the existing paradigms (Bailey and Caprotti 2014). In the face of increasing negative effects of some companies on the natural environment and society, Sustainable Finance (SF) fulfill the world economies demand in a holistic way and play a key role towards sustainable development (Soppe 2008; Scholtens and Sievänen 2013; Busch et al. 2016; Hopener et al. 2019; Yan et al.). On the other hand some authors frame that $\mathrm{SF}$ is unable to offer real solutions to the sustainability challenges (Fletcher 2012; Lazonick 2014; Bracking 2019; Lagoarde-Segot 2019). The main aim of SF is to maximize benefits in environmental, social and governance (ESG) area (European Commission 2018; Ahlström and Monciardini 2021) by ensuring access to long-term capital to businesses creating common value for all stakeholders (Schoenmaker 2019). Together with the development of Sustainable Finance comes the need to formulate clear standards and regulations obliging public interest companies to comprehensively disclose non-financial information related to their ESG performance (Ahlström 2019; Eccles and Klimenko 2019; Zadek 2019). The legal conditions on reporting 
of sustainable finance provided by the European Union (EU), especially Directive 2014/95/EU (NFRD, Non-Financial Reporting Directive), are of key importance, as also in last twenty years ESG ratings significantly gained in relevance (Avetisyan and Hockerts 2017). ESG ratings are the complex indices evaluating ESG performance of the company (Escrig-Olmedo et al. 2010). Moreover, they create the link between stakeholders and entities (Schäfer 2005). It is clear that importance of these ratings is growing due to the expansion of equity markets and the improvement of reporting standards on environmental, social and governance information (Ferri and Liu 2005).

The main purpose of this study is assessment of the evolution of sustainability reporting and ESG ratings in case of European listed companies, in the years 2000-2020. Identification of such trends in Europe should be crucial in an evaluation process of ESG ratings and 2014/95/EU Directive effectiveness especially from the market participants perspective.

In order to achieve set goal, a leading research hypothesis is formulated stating NonFinancial Reporting Directive as a key determinant for sustainability reporting improvement for European listed entities. Additional hypothesis constitutes that applicability of ESG ratings to European stock entities is at low importance and covers only minor amount of all stock companies in Europe. In order to deliver results comparative analysis is used including three main dimensions of comparison i.e. number, net sales and market capitalization of ESG rated European stock companies in relation to results of all listed entities in Europe.

Key reason for undertaking the research is the fact that in the face of negative climate change and worsening social problems there is an increasing demand for clear reporting regulations ensuring the control of harmful companies activity outcome on their environment. Recognition of sustainability reporting accountability gap should also contribute to identification of key area of ailments of current non-financial information requirements and would create the space for future deepened empirical studies on environmental, social and governance reporting standards and ESG ratings.

Research proves that vast majority of European stock companies do not provide ESG performance information in analyzed period, however enterprises that reported nonfinancial information generated most of net sales and market capitalization of European publicly traded entities. Findings of analysis indicate also the size of sustainability reporting accountability gap and confirm that wider group of public interest entities should be a subject of NFRD requirements in future.

\section{Non-Financial Reporting Directive and ESG Ratings Relation}

NFRD is the EU legal framework for regulating non-financial information reporting by certain EU companies. Since becoming law in 2018, the main aim of Directive was to provide high quality non-financial information by publicly traded companies and to influence companies to establish more effective practices in ESG area. Furthermore, implementation of NFRD seeks to allow stakeholders to make better assessments of companies activities outcome in relation to their overall risks and value creation. 
Directive obliges large public interest entities and large capital groups ${ }^{1}-$ as well as large banks and insurance companies whether listed or not - exceeding the criterion of an average number of 500 employees at the balance sheet date during the financial year to disclose non-financial information on the ESG performance. The reporting requirements mandate those companies to include in their annual reports: a description of the business model; definition of policies in the field of environmental protection, social responsibility and treatment of employees, respect for human rights, company board diversity regarding gender, age, education and professions and anti-corruption and bribery; results of applied policies; the main risk areas related to the entity's operations including its business relationships with the environment and its products and services that may have negative impact on ESG area; key non-financial performance indicators based on the company's business profile. NFRD further mandates EU countries to implement sufficient and effective measures to ensure reported ESG information by designated entities is in line with EU guidelines. Reporting of non-financial information in the area of ESG can be done voluntarily by entities that are not covered by 2014/95/EU Directive. All companies may use national, international or European frameworks (such as ISO 26000 for Social Responsibility, OECD guidelines for multinational enterprises or the European Commission's guidance) when reporting ESG information, but are imposed to indicate the source of the principles used. In addition, NFRD includes "comply-or-explain" clauses which allow for non-disclosure of information if made transparent and reasons are given (Directive 2014/95/EU).

As the European Commission (EC) pointed out, the NFRD is not sufficient and should be improved. The scale and quality of the information reported by entities is not comparable, reliable and relevant. Investors and other stakeholders recognize some entities do not provide required information at all (European Commission 2020). In response to NFRD deficiencies, EC is preparing new ESG reporting standards, namely Corporate Sustainability Reporting Directive (CSRD). Commission aim is to adopt first package of CSRD by the end of 2022 so it will be applicable for 2023 financial year, while first reports will be published in 2024. In comparison to NFRD, revised regulation will introduce consistent reporting standards and will cover all listed companies (except microenterprises) with at least 250 employees as well as large private companies not listed on stock exchanges. Furthermore, by 2023, CSRD expects to require third party verification of reported sustainability data, integrate sustainability information in companies annual reports with digitalized sustainability data tag. What is more, auditors will be obliged not only to verify that non-financial statement is included in the report but also to verify the content and the processes behind it (European Commission 2021).

As it was correctly observed by Ferri and Liu (2005), importance of ESG ratings will be growing accordingly to expansion of securities markets and improvements of non-financial information reporting. Given so, it should be expected that adoption of CSRD in 2022 will significantly affect ESG ratings popularity and frequency of usage. Over the past

\footnotetext{
${ }^{1}$ Large company is a company that exceeds at least two of the following three criteria on the balance sheet date: balance sheet total: $20 \mathrm{mln}$ EUR; net sales: $40 \mathrm{mln}$ EUR; average number of employees during the financial year: 250 FTEs. Large group is a group which includes parent and related entities and which, on a consolidated basis at the balance sheet date of the parent, exceeds at least two of the following three criteria: $20 \mathrm{mln}$ EUR; net sales: $40 \mathrm{mln}$ EUR, average number of employees in the financial year: 250 FTEs.
} 
twenty years with the spread of popularity of sustainability, ESG ratings has become widely used by stakeholders interested in screening companies based on non-financial criteria. The emergence of these ratings as new type of company performance measures results from the convergence of interest of different market participants such as companies, regulators and investors.

ESG ratings constitute an easy tool for integration of non-financial factors into quantitative analysis. What is more, ESG scores were created in order to provide transparent and objective evaluation of companies ESG performance and its effectiveness, based on company reported data (Avetisyan and Hockerts 2017). It should be also emphasized, that there is no right or wrong methodology for applying ESG ratings. As currently, there are more than 600 ESG Rating Agencies (ESG RAs) in the market, it is possible that different ESG RAs will give different grades to the same entity. The reason behind - except different methodology used - is also inclusion of different datasets during assessment process. What is more, most of ESG data is used retrospectively, so it is important for ESG Rating Agencies to introduce real-time-latest data.

\section{Research Methodology and Data Collection}

The empirical research results refer to publicly traded companies on European stock exchanges as at 31 December 2020. The selection of this region was dictated by NonFinancial Reporting Directive area of applicability. Choice of all European entities ensures an appropriate degree of representativeness and comparability of the results of empirical research. In order to achieve the objective of the study, a twenty one-years research period was assumed, i.e. 2000-2020, resulting from the need for a long-term ESG ratings evolution assessment and sustainability reporting trends evaluation. During preliminary search it was observed that the earliest assignments of ESG ratings included year 2002, while year 2020 presented incomplete data due to extension of statutory submission deadline for 2020 until 30 June 2021 which was caused by COVID-19 pandemic in Europe. Given above years 2000-2001 and 2020 were excluded from the analysis.

Research was done with use of comparative analysis in two different fields including three categories in each. First, analysis of ESG rating evolution was carried out in 2002-2019 period by comparison of ESG rated Member States public entities with companies of other European countries ${ }^{2}$ and all European public enterprises treated together. Secondly, as NFRD requirements considered EU stock companies only and regulations were adopted in 2018 but published in 2014, research included only Member States listed entities and 20142019 period. In order to assess trends in ESG information reporting, NFRD regulations were applied retrospectively for 2014-2017. In each case results were compared in three dimensions of number of listed companies, their net sales and market capitalization.

Empirical data and ESG ratings for the study were taken directly from the Refinitiv (Thomson Reuters) Eikon database.

\footnotetext{
${ }^{2}$ Group of EU Member States included EU-27 countries, while other European countries included eight countries: Bosnia and Herzegovina, Iceland, Norway, Russian Federation, Serbia, Switzerland, Ukraine and Great Britain.
} 


\section{Results}

Results on ESG rating trends in European publicly traded entities in 2002-2019 period were carried as first. NFRD publication and adoption in European Union and trends in sustainability reporting in that region was analyzed in the following order.

\subsection{ESG rating trends in European listed entities}

Since year 2002 number of European public entities providing high quality nonfinancial information was constantly growing (see figure 1).

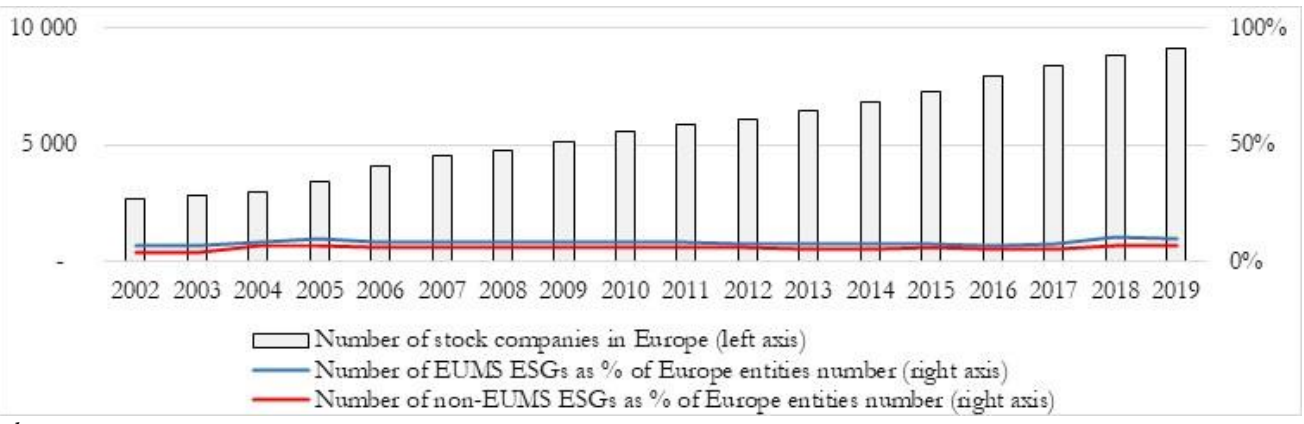

where:

EUMS ESGs - listed companies of European Union Member State (EU-27) with ESG rating assigned, non-EUMS ESGs - listed companies of other European countries ESG rating assigned.

Figure 1. Stock companies structure in Europe in 2002-2019 period

Source: Own research.

The greatest number of non-EUMS ESGs as \% of all European stock companies was noted in 2005 with 6,97\%, while EUMS ESGs had its peak of 10,20\% in 2018. In case of both those periods revised reporting regulations came into force, namely IAS $1^{3}$ in 2005 along with and EU Accounting Directive and NFRD in 2018. In the contrary, minimum percentage values were reached in 2002 for EUMS ESGs as well as for non-EUMS ESGs with respectively $6,70 \%$ and 3,87\% of all European entities. What is more, in each of analyzed years number of EUMS ESGs as \% of number of all European stock companies was higher than number of non-EUMS ESGs. It should be also emphasized that, in 20022019 period, combined number of EUMS ESGs and non-EUMS ESGs at its bottom in 2002 stated 10,57\% and in 2018 at its peak included 16,88\% of all European public companies.

Observed trends proved that as long as there will be no regulations obliging wider group of public interest companies to report on their sustainability, only minor part of all European stock entities will provide ESG performance information on annual basis (see figure 2).

\footnotetext{
${ }^{3}$ International Accounting Standard 1 - Presentation of Financial Statements.
} 


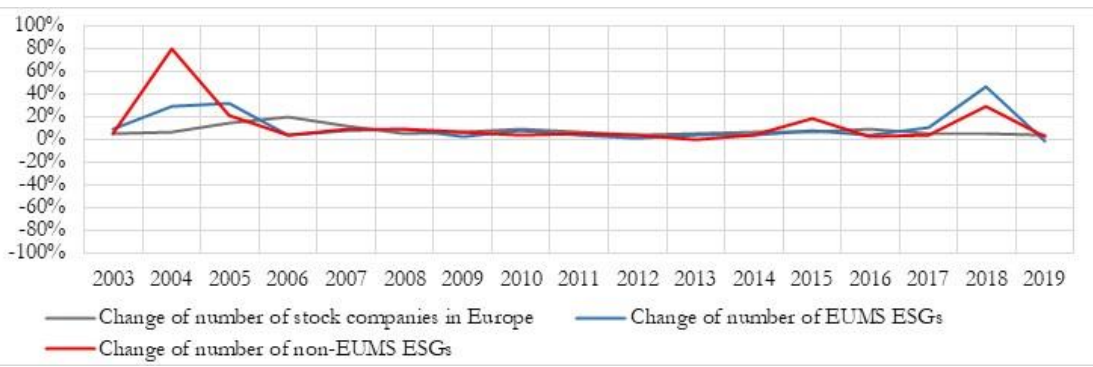

Figure 2. Dynamics of number of stock companies in Europe in 2003-2019 period (in \%)

Source: Own research.

In analyzed years number of EUMS ESGs and non-EUMS ESGs was changing accordingly to number of all European stock companies. In years 2004, 2005, and 2018 the number of EUMS ESGs and non-EUMS ESGs was growing notably faster than the number of all European listed entities together. Increase of 29,08\% and 79,82\% of EUMS ESGs and non-EUMS ESGs respectively in 2004 and further rise of $31,23 \%$ and $21,43 \%$ in 2005 as well as upturns of $45,72 \%$ and $28,82 \%$ in relation to previous years were caused by external factors in the form of non-financial information reporting requirements.

Even though throughout analyzed years EUMS ESG and non-EUMS ESG stated minor number of all listed companies in Europe, ESG rated entities created greater part of European stock companies net sales (see figure 3).

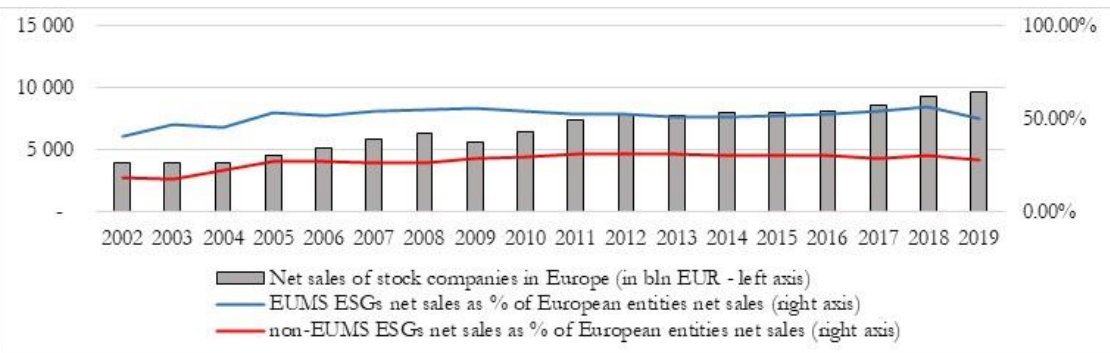

Figure 3. European stock companies net sales structure in 2002-2019 period

Source: Own research.

In years 2002-2019, EUMS ESGs and non-EUMS ESGs generated respectively share in Europe stock companies net sales in range of $40,82 \%-56,79 \%$ and $17,78 \%-31,21 \%$. For EUMS ESGs peak of 56,79\% took place in 2018, while for non-EUMS ESGs maximum it was noted in 2015 with net sales equal to $31,21 \%$ of sales of all European listed entities. What is more, both EUMS ESGs and non-EUMS ESGs reached bottom results of 40,82 $\%$ and $17,78 \%$ in 2003. During time of financial crisis, net sales of EUMS ESGs as well as in case of non-EUMS ESGs were affected to the same extent as aggregated net sales of all European listed companies. This was confirmed by the fact that no exceptional changes of net sales in relation to prior year were recognized during time of recession. However, it was observed that after year 2009 EUMS ESGs suffered slower year to year net sales growth until 2014, while non-EUMS ESGs experienced faster yearly increase of net sales until 2013. Furthermore, combined net sales of all European stock companies with ESG 
rating in 2002-2019 years constituted at least 59,70\% (in 2002) and at most 87,39\% (in 2018).

Yearly changes of net sales of EUMS ESGs and non-EUMS ESGs mostly deviated from trends of all European stock entities net sales only in year 2005 (see figure 4).

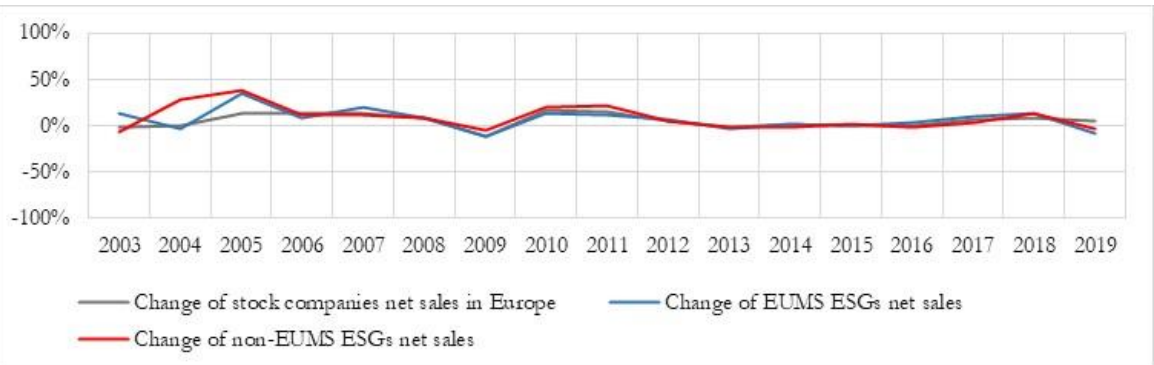

Figure 4. Net sales dynamics of European stock companies in 2003-2019 period (in \%)

Source: Own research.

In most of analyzed years, net sales changes of EUMS ESGs and non-EUMS ESGs were positive and presented direction of change in line to all European public entities. Noticeably higher growth of EUMS ESGs and non-EUMS ESGs net sales than all European stock companies was recognized in 2005. This covered with the time of revised reporting regulation implementation. In 2005 year to year net sales increase for EUMS ESGs and non-EUMS ESGs was equal 34,85\% and 38,33\% respectively while all net sales of all European entities grew by $14,04 \%$. On the other hand, significant net sales downturns were recognized during financial crisis in 2009 (-11,01\% for EUMS ESGs and $-5,38 \%$ for non-EUMS ESGs). This observation proved that while number of European ESG rated listed companies remained unchanged in this year, their financial situation similarly as all European entities got worse. Exceptional results were also noted in 2019 as net sales of all European listed companies grew by 4,58\% in comparison to 2018, while EUMS ESGs and non-EUMS ESGs net sales shrink by 8,06\% and 3,26\%. This confirmed that Europe economy slowdown in 2019 to larger extent affected ESG rated public companies rather than other stock entities.

In terms of market capitalization of analyzed listed entities in the 2002-2019 period, ESG rated companies counted larger part in European stock exchanges (see figure 5).

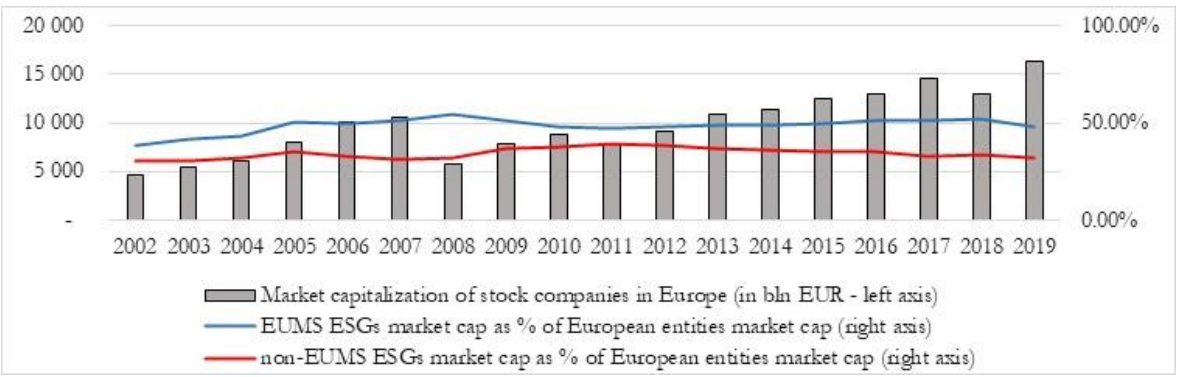

Figure 5. ESG rated companies share in market capitalization of European stock entities in 2002-2019 period Source: Own research. 
In years in which EUMS ESGs market capitalization share in European stocks was increasing in relation to prior year, non-EUMS ESGs share was falling. The largest share of EUMS ESGs companies market capitalization in European stocks was observed in 2008 during time of financial crisis and was equal 54,34\%. In the contrary, non-EUMS ESGs had its peak of $38,90 \%$ in 2011. Observations in 2008 year confirmed that group of EUMS ESGs was perceived as safer type of an investment than other stock companies during time of crisis. On the other hand, the lowest share of EUMS ESGs and non-EUMS ESGs market capitalization in European stocks was recognized in 2002 and counted respectively $38,26 \%$ and 30,21\%. Furthermore, share of market capitalization of EUMS ESGs and non-EUMS ESGs in total of European traded companies market capitalization in analyzed years grew from $68,74 \%$ in 2002 to $80,12 \%$ in 2019 . Identified was also the fact that although EUMS ESGs and non-EUMS ESGs market capitalization share was moving in opposite directions, the gap between market capitalization of those two groups of entities was smaller than in terms of net sales in each of analyzed years.

Based on provided analysis it was observed that EUMS ESGs and non-EUMS ESGs market capitalization dynamics was in line with changes recognized for all European stock companies in 2003-2019 period (see figure 6).

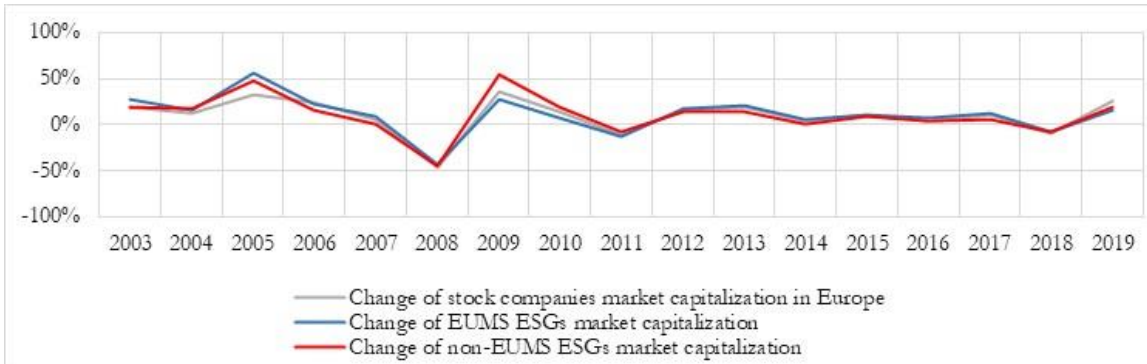

Figure 6. Market capitalization year to year changes of European stock entities in 2003-2019 period (in \%) Source: Own research.

In 2005 market capitalization of EUMS ESGs and non-EUMS ESGs was significantly faster (respectively 55,59\% and 47,12\%) than in case of European entities (32,60\%). Another exceptionally high change of non-EUMS ESGs market capitalization in comparison to all stock entities was noted in 2009 and constituted increase of 53,93\%, in relation to 2008, while European stocks grew by 17,92 percentage points slower. In that time EUMS ESGs market capitalization rose 26,02 percentage point slower than nonEUMS ESGs. During 2010-2018 period, market capitalization of EUMS ESG and nonEUMS ESG entities presented similar changes as noted for all analyzed companies together. What is more, 2019 EUMS ESGs and non EUMS ESGs recognized market capitalization share growth smaller by respectively 9,53 and 7,44 percentage points in relation to increase of all European enterprises of 25,91\%.

\subsection{NFRD trends assessment in case of European Union Member States publicly traded companies}

Number of listed companies European Union Member State being under NFRD regulation was constantly increasing in 2014-2019 period (see figure 7). 


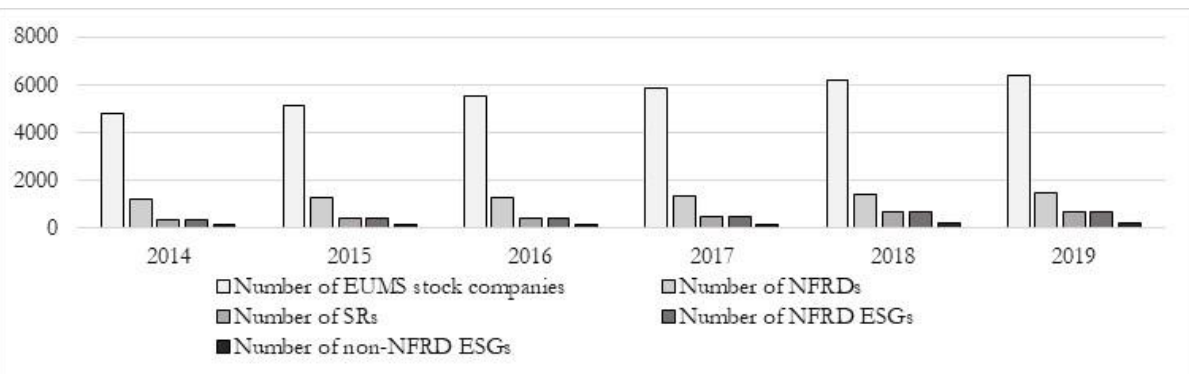

where:

NFRDs - EU-27 stock, companies that fall into NFRD scope, SRs - EU-27stock companies in NFRD scope, publishing ESG information in either Sustainability Reports or companies public websites or other annual reports,

NFRD ESGs - EU-27 stock companies in NFRD scope with ESG rating assigned, non-NFRD ESGs - EU-27 stock companies not in NFRD scope with ESG rating assigned.

Figure 7. European Union listed entities structure in 2014-2019 period

Source: Own research.

In 2014 in scope of NFRD requirements were 1238 entities while in 2019 this amount escalated to 1517 public companies. In each of analyzed years over half of number of obligated EU listed companies did not include non-financial information in their annual reports. What is more, there was no single year in which SR companies assured enough sustainability reporting quality which would allow for rating assignment to all entities. The highest quality of reported non-financial information was noted in 2015 as 405 out of 413 SR $(98,06 \%)$ companies received ESG rating. On the other hand, the lowest quality of reported ESG performance information was observed in 2019 as only 662 out of 723 companies $(91,56 \%)$ were assigned with appropriate rating. Noteworthy is also the fact that in European Union in analyzed period recognized was continuously increasing amount of stock companies which were not in NFRD regulation scope but were publishing non-financial information and received ESG rating. The greatest number of non-NFRD ESGs was observed in 2019 and it included 228 EU stock companies. In 2014-2019 period, entities under NFRD regulation scope were generating increasing part of European stock companies net sales (see figure 8).

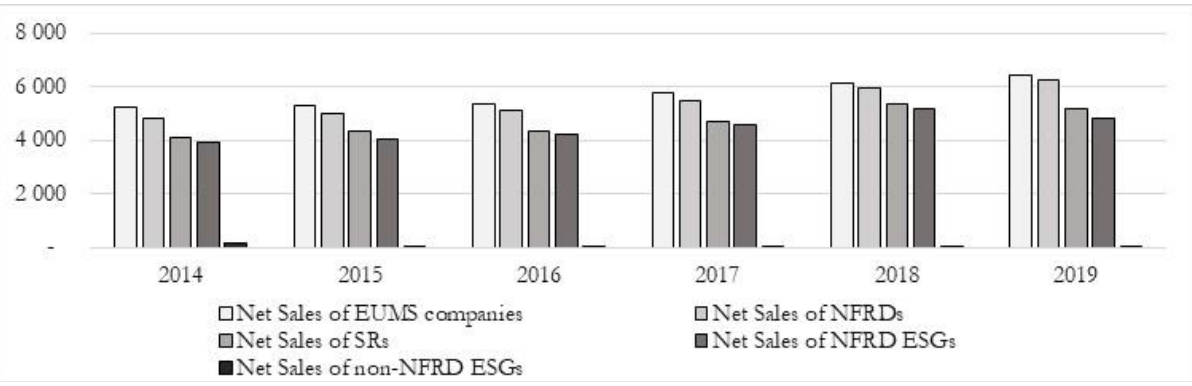

Figure 8. Net sales structure of EU stock entities in 2014-2019 period (in bln EUR)

Source: Own research. 
NFRD regulations in each of analyzed years covered major part of EUMS stock companies net sales. The greatest value of net sales of NFRDs was observed in 2019 and it stated 6256 bln EUR - 97,61\% of all European stock companies net sales. SRs net sales were continuously growing since 2014 from 4112 bln EUR to 5378 bln EUR in 2018. In 2019 observed was decrease of SRs net sales by 206 bln EUR in relation to previous year. The same trend applied to NFRD ESGs as their net sales firstly increased from 3928 bln EUR in 2014 to 5202 bln EUR in 2018 and downturned in 2019 to 4808 bln EUR. Observed net sales decrease of NFRD ESGs in 2019 was caused by EU economy slow down. What is more, in years 2014-2019 for non-NFRD ESGs negative net sales changes were recognized as from 168 bln EUR in 2014 net sales plummeted to 35 bln EUR in 2019.

Similar trends as in case of net sales were identified in terms of market capitalization for most of analyzed groups of entities (see figure 9).

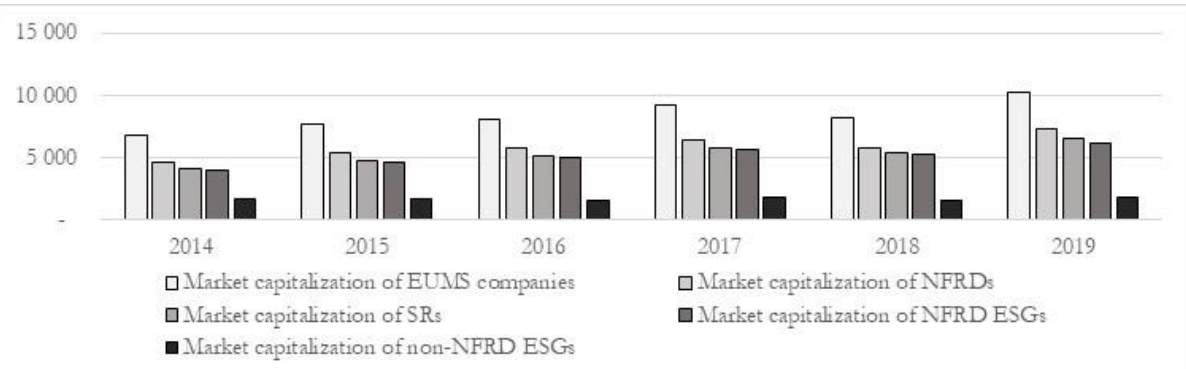

Figure 9. Market capitalization structure of EU listed entities in 2014-2019 period (in bln EUR) (in bln EUR) Source: Own research.

NFRDs market capitalization in 2014-2019 period was changing accordingly to all EU stock exchanges. 2018 was the only year in which market capitalization of EUMS listed companies recognized a downturn of 999 bln EUR in relation to previous year. Furthermore, in 2018 NFRDs companies noted decrease of market capitalization of 698 bln EUR, SRs entities fell by 381 bln EUR, NFRD ESGs by 458 bln EUR and non-NFRD ESG declined by 180 bln EUR. Going onwards, in 2019 exceptional recovery of EU stock exchanges was observed as market capitalization of EUMS entities grew by 2087 bln EUR in comparison to prior year. Similar upturns also applied to NFRDs, SRs, NFRD ESGs and non-NFRD ESGs as in comparison to 2018, those companies gained market capitalization of respectively 1587 bln EUR, 1216 bln EUR, 964 bln EUR and 148 bln EUR. Even though non-NFRD ESGs counted below one twentieth in case of both EUMS number of entities and their net sales in each analyzed year, market capitalization of this group of public enterprises counted almost one forth of market capitalization of EU stock exchanges in 2014-2015 years and around one fifth in 2016-2019 period.

While all ESG rated public companies stated minor number of all EU listed entities, they generated significant share of net sales and counted larger part of market capitalization of EU stock enterprises since year 2014 (see figure 10). 


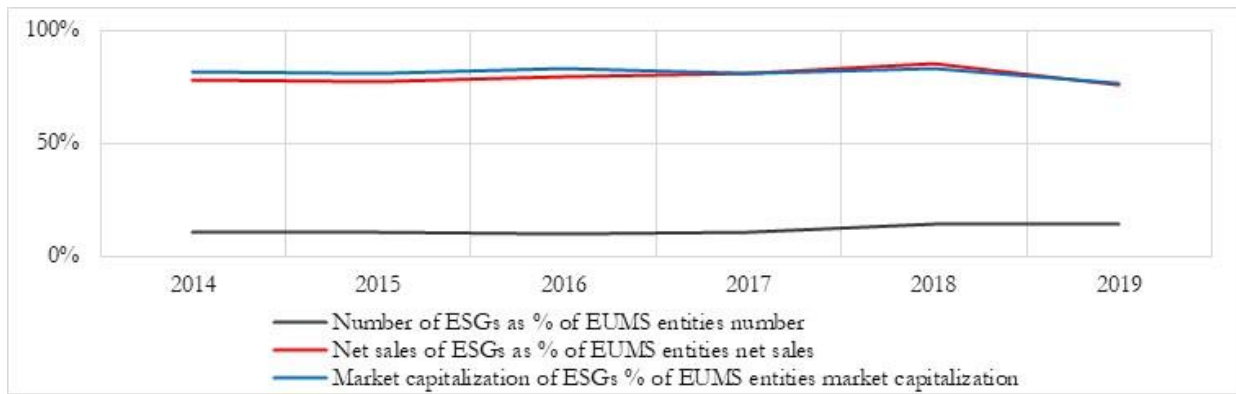

where:

ESGs - all listed companies in European Union with ESG rating assigned.

Figure 10. ESG rated European Union Member State stock entities as share in number, net sales and market capitalization of all European Union publicly traded companies in 2014-2019 period (in \%)

Source: Own research.

In 2014-2019 period ESGs represented no more than 14,56\% (in 2018) of number of all EUMS stock entities however in terms of net sales, ESGs throughout analyzed years generated at least $75,57 \%$ of EUMS net sales in 2019 and at most $85,50 \%$ in 2018 . Similarly recognized was market capitalization share of ESG companies in all listed EU public entities as in 2019 noted was the minimum share of 76,83\%, while in 2018 a maximum of $82,82 \%$ of EU stocks market capitalization was observed. What is more, in each of analyzed year both net sales and market capitalization covered similar part of EUMS listed entities.

\section{Conclusions}

The imposition of reporting obligations in the field of non-financial ESG information is intended to increase the transparency of companies and the consistency as well as comparability of reports disclosed by entities. The information provided on sustainable finance matters also increase the understanding of sustainable development issues which are crucial for the transformation of economic systems towards a sustainable global economy. ESG can be looked at on the one hand as a concept or a way of managing a company, and on the other as a reporting standard. However, it should be noted that ESG reporting by itself does not make company a sustainable entity.

NFRD regulation in the form of future CSRD requirements have to note significant improvements as less than half of obligated EU-27 listed entities provided reports in sustainability area in analyzed period. Even though ESG reporting entities constitute relatively small group of entities in comparison to number of all listed entities in Europe, they generate majority of European listed entities net sales and market capitalization. With that being said, reporting regulations should apply to all companies regardless of type and size as still around $20 \%$ of listed companies net sales (same as market capitalization) remains out of ESG information requirements. What is more, most of exceptional increases were identified during time of adoption of new/revised reporting standards, which proves their effectiveness.

Above research confirmed that the size of non-disclosing ESG information, thus NFRD 
regulations accountability gap, in terms of number of EU listed entities in 2019, constituted $86,05 \%$. If gap was analyzed by net sales of EU-27 publicly traded companies, it stated $24,43 \%$, while in terms of market capitalization $23,17 \%$. Nevertheless, it has to be noted that during analyzed years, ESG ratings and sustainability reporting standards significantly gained on importance and mostly presented increasing trends especially by adoption of Non-Financial Reporting Directive. Provided analysis confirmed main research hypothesis stating NFRD as a key determinant for sustainability reporting improvement for European listed entities. Additional hypothesis constituting that applicability of ESG ratings to European stock entities was at low importance and covered only minor amount of all stock companies in Europe was confirmed.

\section{References}

Ahlström H. (2019). Policy Hotspots for Sustainability: Changes in the EU Regulation of Sustainable Business and Finance. Sustainability, 11(2), 1-22.

Ahlström H., Monciardini D. (2021). The Regulatory Dynamics of Sustainable Finance: Paradoxical Success and Limitations of EU Reforms, Journal of Business Ethics, February, 1-20.

Avetisyan E., Hockerts K. (2017). Consolidation of the ESG Rating Industry as an Enactment of Institutional Retrogression. Business Strategy and the Environment, 26(3), 316 -330.

Bailey I., Caprotti F. (2014). The Green Economy: Functional Domains and Theoretical Directions of Enquiry. Environment and Planning A: Economy and Space 2014, 46(8), 1797-1813.

Bracking S. (2019). Financialisation, climate finance, and the calculative challenges of managing environmental change. Antipode, 51(3), 709-729.

Busch T., Bauer R., Orlitzky M. (2016). Sustainable development and financial markets old paths and new avenues. Business \& Society, 55(3), 303-329.

Choi J., Wang H. (2009). Stakeholder relations and the persistence of corporate financial performance. Strategic Management Journal, 30(8), 895-907.

European Parliament (2014). Directive 2014/95/EU amending Directive 2013/34/EU as regards disclosure of non-financial and diversity information by certain large undertakings and groups.

Eccles R. G., Klimenko S. (2019). The investor revolution. Harvard Business Review, 97(3), 106-116.

Escrig-Olmedo E., Muñoz-Torres M.J., Fernandez-Izquierdo M.A., (2010). Socially responsible investing: sustainability indices, ESG rating and information provider agencies. International Journal of Sustainable Economy, 2(4), 442-461.

European Commission (2018). Financing a Sustainable European Economy.

European Commission (2020). Review of the Non-Financial Reporting Directive.

European Commission (2021). Impact assessment.

Directive 2014/95/EU amending Directive 2013/34/EU as regards disclosure of non-financial and diversity information by certain large undertakings and groups. Retrieved from https://eurlex.europa.eu/legal-content/EN/TXT/PDF/?uri=CELEX:32014L0095\&from=PL

Ferri G., Liu L. (2005). Assessing the effort of rating agencies in emerging economies: Some empirical evidence, European Journal of Finance, 11(3), 283-295.

Fletcher R. (2012). Capitalizing on chaos: Climate change and disaster capitalism. Ephemera: Theory \& Politics in Organization, 12(1), 97-112.

Hoepner, A. G. F., Majoch, A. A., Zhou, X. Y. (2019). Does an asset owner's institutional setting influence its decision to sign the principles for responsible investment? Journal of Business Ethics, 168, 389414.

Lagoarde-Segot T. (2019). Sustainable finance. A critical realist perspective. Research in International Business and Finance, 47, 1-9.

Lazonick W. (2014). Profits without prosperity. Harvard Business Review, 92(9), 46-55.

Rappaport A. (1986). Creating shareholder value: The new standard for business performance, Free Press

Schäfer H. (2005). International corporate social responsibility rating systems: conceptual outline and empirical results. The Journal of Corporate Citizenship, 20(1), 107-120. 
Schoenmaker D. (2019). A Framework for Sustainable Finance, Rotterdam School of Management.

Scholtens B., Sievänen R. (2013). Drivers of socially responsible investing: A case study of four Nordic countries. Journal of business ethics, 115(3), 605-616.

Soppe A. (2008). Sustainable Finance and the Stakeholder Equity Model. In C.J. Cowton, M. Haase (Eds.), Trend in Business and Economic Ethics, (pp. 199-228). Springer Verlag.

Yan S., Ferraro F., Almandoz J. (2019). The rise of socially responsible investment funds: The paradoxical role of the financial logic. Administrative Science Quarterly, 64(2), 466-501.

Zadek S. (2019). Financing a Just Transition. Organization \& Environment, 32(1), 18-25. 